\title{
6
}

\section{TEACHERS LEARNING ABOUT ENGLISH AS A LINGUA FRANCA ON FACEBOOK: INSIGHTS FROM A COMMUNITY OF PRACTICE ${ }^{1}$}

\author{
PROFESSORES APRENDENDO SOBRE INGLÊS \\ COMO LÍNGUA FRANCA NO FACEBOOK: \\ INSIGHTS DE UMA COMUNIDADE DE PRÁTICA
}

\author{
Luciana Cabrini S. Calvo ${ }^{2}$ \\ Universidade Estadual de Maringá, Brazil \\ Michelle El Kadri ${ }^{3}$ \\ Universidade Estadual de Londrina, Brazil \\ Telma Gimenez ${ }^{4}$ \\ Universidade Estadual de Londrina, Brazil
}

\begin{abstract}
Communities of practice is a concept widely adopted by teacher educators affiliated with a practice-based education and situated learning. It provides a lens to examine how experienced and novice teachers engage in collaborative problem-solving and learn from each other in emergent interactions. Both face-to-face and virtual communities of professionals provide room for learning opportunities, with dynamic trajectories from more peripheral to more central forms of participation. According to this theoretical framework (LAVE; WENGER, 1991; WENGER, 1998; WENGER et al., 2002, 2011), teachers learn from engagement with others and build their understandings upon interactions focused on the practice of the community. ELF is a concept that is not yet reified among English language teachers in Brazil but is beginning to catch the attention of a wider group of professionals, since English is now compulsory in basic education and the national curriculum defines English as a lingua franca. In this paper we analyze interactions in a Facebook community of teachers (BrELT Brazil's English Language Teachers) who, over a period of two months, discussed the meanings of ELF
\end{abstract}

1 This paper is based on a presentation at ELF 11, held in London in July 2018.

2 cabrinisimoes@gmail.com

3 mielkadri@hotmail.com

4 tgimenez@uel.br 
and how it was/could be contextualized in their classrooms. We looked into the various ways in which the sharing of information and experiences were displayed and the strategic resources employed to advance their learning on this theme. The BrELT group reconstructed their knowledge on ELF, interacting in democratic ways and showing how they care about their domain. Also, the group revealed to be a potential learning site, as they engaged in the activity and negotiated new meanings. Finally, the BrELT community illustrates how social media can play an important role in teacher development, as it can bring together professionals with different levels of expertise who are willing to share their experience.

Keywords: English as a Lingua Franca; Communities of Practice; Social media.

Resumo: Comunidades de Prática é um conceito amplamente adotado por formadores de professores afiliados a uma formação baseada na prática e à aprendizagem situada. Ele fornece lentes para examinar como professores experientes e novatos se engajam em resoluções conjuntas de problemas e aprendem uns com os outros em interações emergentes. Tanto as comunidades profissionais virtuais como as presenciais fornecem espaço para oportunidades de aprendizagem, com trajetórias dinâmicas de formas de participação mais periféricas a centrais. De acordo com esse referencial teórico (LAVE; WENGER, 1991; WENGER, 1998, 2012; WENGER et al., 2002, 2011), professores aprendem por meio do engajamento com outros e constroem seus entendimentos nas interações focadas na prática da comunidade. ILF é um conceito ainda não reificado entre professores de inglês no Brasil, mas está começando a atrair a atenção de um grupo maior de profissionais, já que a língua inglesa é agora obrigatória na educação básica e o currículo nacional define inglês como língua franca. Neste artigo analisamos as interações de uma comunidade de professores no Facebook (BrELT Brazil's English Language Teachers - Professores de língua inglesa do Brasil) que, por um período de dois meses, discutiram os significados de ILF e como ela era/poderia ser contextualizada em suas salas de aula. Investigamos as várias maneiras que o compartilhamento de informações e experiências eram manifestadas e os recursos estratégicos empregados para promover suas aprendizagem neste tema. O grupo BrELT reconstruiu seus conhecimentos em ILF, interagindo de modo democrático e mostrando como se importam com seu domínio. Ainda, o grupo revelou ser um contexto potencial de aprendizagem, pois os participantes se engajaram na atividade e construíam novos sentidos. Por fim, a comunidade BrELT ilustra como mídias sociais podem desempenhar um papel importante no desenvolvimento docente já que reúne profissionais com diferentes níveis de conhecimento que estão dispostos a compartilhar suas experiências.

Palavras-Chave: Inglês como Lingua Franca; Comunidades de Prática; Mídias sociais.

\section{INTRODUCTION}

Social theories of learning have acquired great prominence with the development of a theoretical lenses that illuminate how people learn together and develop themselves as they engage in activities aimed at achieving a common goal. One such concept is communities of practice (CP) (LAVE; WENGER, 1991; WENGER, 1998, 2012; WENGER ET AL., 2002), adopted in many disciplinary areas and by teacher educators affiliated with a practicebased education and situated learning. It provides a lens to examine how 
experienced and novice teachers engage in collaborative problem-solving and learn from each other in emergent interactions.

Both face-to-face and virtual communities of professionals provide room for learning opportunities, with dynamic trajectories shaped by different forms of participation. In such communities, teachers learn from engagement with others and build their understandings upon interactions focused on the practice of the community. Thus, learning, in this perspective, can be understood as a form of social participation, shaping and transforming identities in the process of constructing and negotiating meaning (WENGER, 1998).

Taking into account the $\mathrm{CP}$ framework, this article focuses on the interactions of a Facebook community of about 18.000 teachers - the BrELT

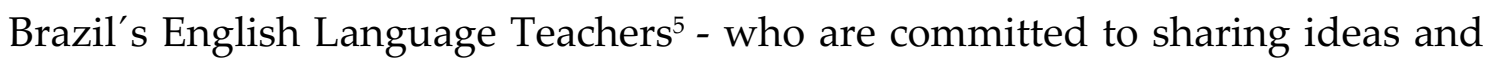
resources among English teachers. Questions pertaining the adoption of a lingua franca perspective into their teaching triggered a series of responses that exemplify how teachers can learn from each other about English as a Lingua Franca (ELF) by interacting on social media.

In this paper we uncover their understandings about ELF and how they were reshaped by the sharing from more experienced peers through the analysis of their ways of acting/interacting (FAIRCLOUGH, 2003) as they participated in the BrELT Group. The next section brings a discussion on CP, presents the BrELT Facebook group and its characterization as a $\mathrm{CP}$; then, the analytical procedures are explained and the corpus analyzed. Afterwards, some remarks are made on the initial and final understandings about ELF and on how the group constructed meaning on ELF in the Facebook group. We conclude by considering the implications for continuing professional development in communities of practice.

\section{COMMUNITIES OF PRACTICE AND THE BRELT COMMUNITY}

CPs can be defined as groups of people with common goals and interests who interact continuous and regularly aiming at developing themselves in a particular domain (WENGER, 1998, 2006). The concept is used as a lens, in many different areas, to analyze initiatives that bring together professionals

5 www.facebook.com/groups/brelt. 
with varied degrees of expertise to establish a kind of "learning partnership" (WENGER ET AL., 2011).

For Wenger et al. (2002), CPs can have many different forms (small/big; long-lived/short-lived; collocated/distributed; homogeneous/heterogeneous; inside/across boundaries; spontaneous/intentional) and can go through different stages of development ${ }^{6}$, which are characterized by the activities developed and by the interactions and relationship of their participants.

There are different levels of participation in a CP, i.e. not everybody participates in the same way: there are members who take leadership roles and others who participate more peripherally (WENGER ET AL., 2002). For the authors, there is the "core group" (10-15\%), considered the "heart of the community" formed by its coordinators; then, the active group (15-20\%) formed by those who participate regularly, but not with the intensity of the first group; and the peripheral group (the majority of the members) who rarely participates, and just observes the interaction of the other members:

Some remain peripheral because they feel that their observations are not appropriate for the whole or carry no authority. Others do not have the time to contribute more actively. [...] the people on the sidelines often are not as passive as they seem [...] they gain their own insights from the discussions and put them to good use. [...] In their own way, they are learning a lot. (WENGER ET AL., 2002, p. 56)

As the authors continue, in addition to these three categories, there are people surrounding the community who are not members, but have an interest in it. As the limits of these categories are not fixed, the members transit through them, having different forms of participation:

Core members often join the sidelines as the topic of the community shifts. Active members may be deeply engaged for a month or two, then disengage. Peripheral members drift into the center as their interests are stirred [...]. The key to good community participation and a healthy degree of movement between levels is to design community activities that allow participants at all levels to feel like full members (WENGER ET AL., 2002, p. 57).

6 The development stages of a CP mentioned by Wenger at al. (2002, p. 69) are: potential; coalescing; maturing; stewardship; transformation. 
We have all participated of many $\mathrm{CPs}$, but not every community (e.g. "a neighborhood") is a CP; neither all practices (e.g. "play the piano") makes one CP to emerge (WENGER ET AL., 2002, p. 41). Three elements are fundamental to characterize a group as a community of practice: i) the domain of knowledge; ii) the community of people and iii) the practice:

i) The domain is the body of knowledge (specialized or not) of the community, it is what makes the $\mathrm{CP}$ singular, distinguishing it from other groups. It creates "common ground and a sense of common identity" (WENGER ET AL., op. cit., p. 27). For the authors, the domain is considered the "raison d'être" of a CP, as it connects people together and guides their learning.

ii) The community "creates the social fabric of learning" (WENGER et al, 2002, p. 24), it encourages interactions and relations that enable the members to learn together. "It is a group of people who interact, learn together, build relationships, and in the process develop a sense of belonging and mutual commitment" (WENGER et al., op. cit., p. 34). According to the authors, for a $\mathrm{CP}$ to be formed, people need to interact regular and continually. Also, it is important to highlight that, although the term "community" expresses the idea of homogeneity and commonality, it is not characterized as such: diversity and conflicts are part of CPs.

iii) The practice refers to ways of doing things in their domain: "a set of common approaches and shared standards that create a basis for action, communication, problem solving, performance, and accountability" (WENGER ET AL., op. cit., p. 38). The members develop shared and common resources that bring together the community. These resources include: "cases and stories, theories, rules, frameworks, models, principles, tools, experts, articles, lessons learned, best practices, and heuristics" (WENGER ET AL., op. cit., p. 38).

It is the combination of these elements "domain, community and practice" that forms a CP: the domain establishes the common focus; the community provides the joint learning and the practice focuses learning on what people do (WENGER, 2004). 
Many studies in the teacher education field have used the CP framework to analyze teachers' interactions in groups. They focus on virtual (COSTA, 2007; PERIN, 2009) or face-to-face communities (HERRINGTON ET AL., 2008; HALU, 2010; CALVO, 2013) with teachers from different levels and areas of education (KIMBLE; HILDRETH; BOURDON, 2008). Because social media communities of professionals can be characterized as CPs, we adopted this framework to investigate how the concept of English as a Lingua Franca (a relatively recent topic in English language teaching in Brazil) would be addressed by a group of professionals using the resources afforded by Facebook.

\section{THE BRELT COMMUNITY}

The closed group was created in 2011 and in June 2018 it had a membership of 18,886 . They exploit all forms of social media by maintaining a Facebook page (www.facebook.com/groups/brelt), a blog (Blog: http://breltchat.wordpress.com/), a Twitter account (@breltchat), Instagram (@brelt_brelt), a YouTube channel (BrELTChatchannel) and an e-mail address (breltchat@gmail.com). According to their description,

BrELT is a global ELT community made by Brazilians. We welcome practitioners, teacher trainers, managers, coordinators, content developers and researchers from both the state and private sectors. One of our main initiatives is BrELT On The Road (BOT), our annual, internationally recognized event that aims to bring ELT professionals the best of what is currently being discussed in our field and also explore what the future holds ${ }^{7}$.

The group welcomes messages about conferences and other development opportunities, language issues, curiosities about English, news about English Language Teaching (ELT) among other related topics. Since 2018 it also organizes the ELF Week, a series of webinars aimed at introducing and discussing ELF.

BrELT is a CP because it is formed by practitioners who have a domain (the teaching of English), a community (a "global community made by

7 Available at: <www.facebook.com/groups/brelt>. Access: May 6, 2019. 
Brazilians" who are interested in learning from each other), and a practice (EFL) that is shared through social media, i.e. it is a virtual community.

\section{METHODOLOGY}

As we have already mentioned, the purpose of the study was to identify how members of this CP negotiated their understandings of ELF, triggered by a question posed by one of its members on January 1, 2018:

Does anyone here teach in ELF perspective instead of EFL? Why did you move to this practicing? Could you give your impressions?"

There were 233 comments on this question, with the last one posted on February 2, 2018, as follows:

I though some of you may be interested in Katy Simpson's upcoming (starts Feb 4th) course with iTDi on creating an ELF-Aware classroom. Katy's plus a group of teachers from more than a dozen countries have put together an exciting course. here's her course page: http://itdi.pro/.../creating-elf-aware-classroom-katy.../)

The comments were copied and divided by sub-threads. Each sub-thread was initiated by a member as an independent comment or a question (not as a direct reply to a comment/question of another member), as exemplified below:

Sub-thread 2: ELF is English as a Lingua Franca, right? I get real lost with these acronyms.

The analytical procedure enabled the identification of one thread that initiated the discussion and 24 sub-threads. In order to understand how the group constructed their understandings about the concept, we classified their "ways of acting/interacting" (FAIRCLOUGH, 2003) during their interactions according to their functions in contributing to a shared repertoire. According to Fairclough (op. cit.), in social practice, discourse figures as ways of acting/interacting (genre), ways of representing (discourse) and ways of being (styles). For the author, "One way of acting and interacting is through speaking or writing, so discourse figures first as "part of the action'" (p. 26). 
The next section will present those understandings. The group agreed to have their comments analyzed and quoted anonymously.

\section{UNDERSTANDINGS ON THE MOVE}

In this section, we explore how the group reshaped the understandings about ELF by following the main thread, which triggered 14 comments.

Excerpt 1: Terminology and confusion

1 André : Does anyone here teach in ELF perspective instead of EFL? Why

2 did you move to this practicing?

3 Bruna: I have to. $\because$ :) It's English for specific purposes to air traffic

4 controllers.

5 André: Could I say that ESP is also an ELF? I'm having this subject at post-

6 graduation, and although it's quite a pain in the ass to get all WE

7 meanings, I'm having a blast.

8 Carol: Bruna, now you got me puzzled. I've had a different conception

9 of ELF so far. Teaching ESP to air traffic controllers is not just ESP?

10 Bruna: Carol it's an esp in a lingua franca environment, so we teach within 11 an elf perspective.

12 André: Bruna you mean, Let It Pass perspective?

13 Bruna: Can't type much right now. On a coach. But I do want to keep this 14 going. Will come back here tomorrow at the latest. Do tag me if I don't 15 please.

16 Bruna: But the quick answer is no. To me equating elf to let it pass is a 17 misconception of what elf is. "Let it pass" is one of the translingual 18 strategies.

19 Mara: André world Englishes is a different thing tho $\odot \cdot$ ELF is in the 20 Global Englishes umbrella but has moved away from WE.

21 Carol: OMG guys, now you got me definitely lost in this conversation, lol.

22 André: That's what I said up there about WE $-\theta$

23 Mara: hahaha maybe I should just make a list of the acronyms and

24 abbreviations because it is confusing indeed. Don't worry. Haha

25 WE: world Englishes- it's about variations like Indian English or Chinese

26 English

27 Global Englishes: umbrella term for ELF, WE and others Englishes uses

28 ELFx EFL: língua franca is related to use of English in the users terms 
whilst EFL suggests users are always learning a language that's not their own.

31 Paulo: Mara there's also EIL (English as an International Language). Jenkins used it in her early studies and then moved to ELF for a few reasons. I'm writing an assignment on ELF orientation to pronunciation teaching so I'd appreciate it if you could comment on the differences between EIL and ELF their current usage in research $\because ;-8$ Mara: EIL and ELF are the same in ELF research. It was just a term used before they came up with ELF. Nobody uses it for the purpose of describing ELF nowadays I guess Paulo: Mara I have seen some authors use the terms indistinctively whereas others stress the differences and favor the use of ELF. but I guess

40 it also depends on when the texts were written. Thanks

41 Mara: Paulo yeah, and also if it's an ELF researcher or not. There are some researchers from WE or other areas who collaborate to ELF research and usually just use them interchangeably. It's ok, it's just a matter of which is more up to date than the other

In this interaction, there are five participants: André, Bruna, Carol, Mara and Paulo. Bruna is the first to associate ELF with English for Specific Purposes (ESP), a context where she teaches. She sees herself as a teacher who has to do it (line 3). After André questions again if "ESP is an ELF", Carol feels confused with this idea and tries to clarify it by asking Bruna if ESP is not something different (lines 6-7). Bruna replies that air traffic controllers use ELF and, therefore, she has to teach within an ELF perspective (line 8). André (who is struggling with the notion) tries to elicit more information from Bruna, by exemplifying it with what he sees: ELF associated with air traffic controllers ('let it pass" principle). Bruna disagrees with what she views as a misconception and defines the principle as a translingual strategy (lines 12-13). At this point it is easy to see that these teachers have come across some of terms found in the ELF literature and are reasoning together to arrive at a shared meaning by making reference to them.

Mara joins in picking up on something that André had said earlier (line 5), when he mentions WE (World Englishes). She tells him that ELF is not the same as WE, while still being part of "Global Englishes". Carol, jokingly, confesses being confused again and André explains that he used WE in the same sense of Global Englishes (line 17). Mara, then, makes a suggestion of compiling a glossary to facilitate comprehension and provides information 
about the distinctions (lines 21-23). In this segment, Carol is engaged in trying to understand what ELF is, while André seems to be a stage ahead but still adopting terms which are further clarified by Mara, who seems to be the experienced member when it comes to ELF. She is joined by Paulo, who adds English as an International Language as another acronym he found in his studies (lines 24-27) and asks Mara to comment on the differences according to recent research. Mara replies it is just another acronym used before ELF and probably not used in this research paradigm anymore (line 29). Paulo reports his experience in coming across both terms used interchangeably, and speculates on the reasons being attributed to the dates when the texts were written, thus corroborating Mara's understanding that more recent uses favor ELF instead of EIL (lines 30-31). Mara complements by hypothesizing it might also be explained by the researcher's alignment with ELF, acknowledging that researchers associated with WE or similar conceptualizations may also use them interchangeably. She reinforces the understanding that it is a question of which is more recent (lines 33-35).

In Excerpt 1, it is clear that the various acronyms coexisting in the literature on the global spread of English are a source of difficulty for teachers interested in learning more about ELF. Both Paulo and Mara seem to be studying this topic and are willing to clarify, although Paulo seems to be still struggling with the acronyms. He sees Mara as an expert to whom he directs the request to explain the differences ( $I^{\prime} d$ appreciate it if you could comment) and help with his assignment. She performs this role by being categorical when defining the terms (lines 21-23).

In Excerpt 2, André makes a statement about ELF being a better perspective for teaching English and Carol joins in by addressing the conversation on acronyms and meanings discussed in Excerpt 1 . In this interaction there are four participants: André, Carol and Mara who were already interacting in Excerpt 1 and a new interlocutor: Luiz. Despite André's attempt to move forward in considering the benefits of ELF for language teaching, the conversation goes back to definitions, revealing how much work needs to be done to make the concept more transparent to teachers.

\section{Excerpt 2: ELF and broken English}

45 André: There's tons of analysis saying ELF is better then EFL in nowadays

46 Teaching, and it graspped me

47 Carol: I really went to my old university books for double checking. But 
ELF means 'any sucessful communication between two non-native speakers, regardless of grammar incorrectness and often using more than only one language at the same time for getting a point across'.

André: Carol THIS

Carol: Efficiency more important than correctness. Our so-called BROKEN ENGLISH.

Carol: In my humble opinion, there's a fine line which divides ELF/Broken English of something rather incomprehensible and often based on body language/miming.

Luiz: English as a Lingua Franca is NOT broken English, but Mara can explain that much better.

Carol: That is going to be very interesting. As it's not my area, I really double-checked to avoid saying something stupid. But I'm really open to learn new points of view.

Luiz: It is interesting indeed. Not my area of expertise/ study either, but I learned it is not broken English. It's a lot about not having the focus on the native speaker as I understood, but I feel I need to learn more.

Carol: English as a lingua franca (ELF) can be thought of as "any use of English among speakers of different first languages for whom English is the communicative medium of choice, and often the only option." (Seidlhofer 2011: 7) Seidlhofer, Barbara. 2011. Understanding English as a Lingua Franca. Oxford: OUP. But I do admit, it's not really something I know a lot about. So, if it's Mara's specialty, I really want to listen to her explanation about it.

Mara: That's the main definition of ELF indeed but the thing is that ELF is evolving to a multilingual / translingual perspective now and this might have a slight change soon $\because \%$

Carol: That's pretty interesting, in fact. I have always said I have worked with ESP for over 20 years, but what I called ESP then is not what I deliver today. ESP has changed a great lot. I guess that's the same with ELF.

Carol disregards André's statement and wants to make sure she understands what ELF is (lines 38-40). Perhaps skeptical of what had been said before, she goes back to her "old university books" and concludes that it is "broken English", but recognizes that the books might be wrong. Luiz contests that idea quite strongly (NOT broken English- line 49) and asks for Mara's help, and also admits it is not his "area of expertise", although believing that "it's a lot about not having the focus on the native speaker" (lines 55-56). Both Carol and Luiz reveal openness to learn (lines 56 and 62). 
Carol keeps her strategy of relying on books by quoting one of the leading authors in this field and invites Mara to comment. Mara legitimizes the definition and adds that the concept has been evolving (lines 63-64). This excerpt shows the reinforcement of Mara's expert role, recognized as such by members of the group, and gladly accepted by her.

These two excerpts at the beginning of the discussion reveal that the participants are struggling to find a common definition that is shared in the community. Their understandings about ELF can be summarized as follows:

- ELF is a synonym for ESP

- ELF is better than EFL

- ELF is a "let it pass" principle

- ELF and EIL are different approaches to teaching

- ELF is/not Broken English

- ELF is about not having the focus on the native speaker.

These meanings are made explicit and confirmed or rebuked by other members of the group. A leadership role is assigned and accepted by one of the members (Mara), who provides definitions and quotes from external sources to legitimize her contributions.

The next sub-thread 3 starts with Luiz sharing his personal experience when Mara observed his class and pointed out he was ELF-aware.

\section{Excerpt 3: ELF in practice}

78 Luiz: To be honest, the idea of ELF is still really new to me. Someone

79 observed a lesson of mine recently and said I was aware of ELF in the way I

80 corrected students and I was really flattered, lol. But if you ask me how to

81 teach ELF, I'm not sure I can answer your question.

82 Mara:

83

84 André: Could you tell/describe us this particular class and how you were

85 evaluated? I mean, what have you been told about this ELF awareness?

86 Luiz: I think Mara can explain it better. $\because$ :)

87 Mara: I observed his class for one of my assignments and even though Luiz

88 does not know what ELF is, his class was very influenced by the ELF

89 perspective. Alessia Cogo is researching the Brazilian ELF development

90 and I was in her talk about it here in Southampton and one interesting

91 thing she pointed is that because we are so influenced by Paulo Freire's 
92 critical pedagogy, understanding the aim of an ELF perspective or even

93 applying it is not as much of a problem in Brazil.

As André is interested and asks him to describe his classes and explain this "ELF awareness" (lines 75-76), Luiz invites his observer (the experienced peer) by asking her to explain (line 77). It is clear that, although Luiz may be adopting ELF practices, he does not recognize it as such or does not have enough understanding of ELF to analyze his class using this perspective. The expert accepts her role and explains his class was influenced by an ELF perspective. The expert mentions another well-known researcher's impression on the Brazilian context in order to affirm that it is perhaps easier for Brazilian teachers to adopt ELF because of Paulo Freire's influence. Also, in this case, the expert role is accepted by Mara who asserts the evaluation she had made of Luiz's class, drawing on well-known researchers to support her answers.

The leadership role is fully enacted by Mara, as shown in Excerpt 4 .

\section{Excerpt 4: Learning with the more experience peer}

94 Mara: Ok, I will try to make it as clear as possible because sometimes I get

95 a little overwhelmed with the amount of complexity involved in ELF.

96 First, ELF cannot be taught. Yep, it is not really something to be taught,

97 because as somebody already mentioned, ELF is any communication

98 through English. So, many times people speaking ELF were not even

99 taught in a formal classroom how to speak English. But, what can change

100 English education is an ELF awareness. For ELF awareness of teachers and

101 students, first we need to change the whole ELT industry from textbooks

102 to teacher training because the focus is not the native speaker. Standard

103 English is not real for ELF in the sense that it is not achievable, because as

104 we know, Standard English is either BBC English or "American" English.

105 Secondly, ELF is related to accepting languages evolve, and English which

106 is not a native language, in the case of England or the USA, is not at all

107 related to native speakers and we should not conform to their rules

108 because ENL and ELF are totally different things. It means we can speak

109 whatever English we want? No, languages do need to follow a pattern so

110 its comprehensible, however, what ELF research argues is that rules can

111 change, and certain rules have being changing because of the use of ELF.

112 Lastly, ELF and EFL are total opposites for one reason, and you might

113 teach English on a ELF perspective and you don't even know. EFL implies

114 everyone speaking English who is not from English speaking countries are

115 "foreigners" to the language and it cannot be owned by those foreigners, 
116

117

118

119

120

121

122

123

124

125

126

127

128

129

130

131

132

133

134

135

136

137

138

139

140

141

142

143

144

an ELF perspective on teaching empowers teachers and students to own the language for local and global use, whatever fits better to each context. Martin Dewey and AlessiaCogo write a lot about ELF in ELT, and Telma Gimenez and Savio Siqueira have written about it too in the Brazilian context.

Carol: Thanks, Mara. That was really clarifying for me.

André: It seems to be the Holly Grail for me. 28

Mara: I had to go back to my notes to write this post... hahhaha

Carol: You're lucky. Going back to my notes I jumped to the conclusion

ELF was the same as broken English. To be honest with you, I still did not really get the difference...

André: Mara is there any link describing an ELF example in real situation? I mean, this awareness of what Luiz has said?

Mara: Example: If you are teaching listening and the audio you use is of a real life situation of intercultural communication without any native speakers (or if a native speaker, native speakers can be part of ELF too). Like a person from Brazil and another from Italy talking in English.

Mara: There are some ELF corpora which are very interesting to observe how ELF is used. You can look it up. I think there is also a Brazilian ELF corpus already too

André: Mara hmmmmmmmmmmmmm

Mara: Or even for writing.... but then you would have to deconstruct a lot more of biases, which has been hard even for me $\because:($

Laura: Wow, Mara. Thank you so much! I kinda have been aware of ELF, but I didn't know It was ELF let's say. I have been standing up for other kinds of English since I went to Indonesia and lived there for 7 months working at a multinational and teaching English. From that moment on this focus on native speakers made no sense for me anymore. I will definitely study more about ELF!

Mara articulates a long comment to explain how ELF fits into teaching. The excerpt shows Mara, Carol and André interacting with a further comment by Laura who made her first contribution. Here Mara takes on a teacher's role and provides information based on her notes (line 113). She contextualizes ELF based on its use and its implications for teaching. She does so by comparing it to EFL and ENL and by emphasizing a) the decentering of native speaker (lines 92-93; 97-98) and b) the misconception that "anything goes" (lines 99-101). She finishes her comment stressing how empowering the perspective might be for non-native speakers. 
Some participants react to her explanation by expressing gratitude/recognizing information brought by her as being relevant. Carol, who was at first puzzled, thanks her, despite feeling still confused (line 115) and André wants to get more references on ELF awareness (lines 117-118), i.e. they evaluate the topics discussed. As Carol mentions that she does not see the difference, André jumps in and asks the expert to give practical examples. She refers to corpora including a Brazilian one. Laura recognizes the value of ELF after Mara's explanations by linking it to her own experience abroad, becoming aware of something that was not her first topic of interest.

In Excerpt 5, the expertise available in the group is acknowledged by some members and there was a suggestion that the contributions could be transformed into a formal course.

\section{Excerpt 5: Expanding learning about ELF}

145 Cristina: I come to this thread whenever I wish to enhance my

146 understanding of ELF. It's so wonderful to learn it here. I believe this is

147 one of the best groups here on facebook. Mara, you're awesome. Thank

148 you for your posts.

149 Mara: $\bullet$ teachers from this amazing group are my inspiration

150 to learn more and more so I can share with all of you.

151 Cristina: Acabei de ler o "postão' supermega aula da Bruna. You rock,

152 menina!!! Tô achando que o BrELT vai acabar virando uma pós EAD. Que

153 aulão magnífico. É pra copy \& paste e ler várias vezes para consolidar.

154 ().

155 Bruna: Hahhahhaah textão - trabalhamos. Aprendo muito por aqui tb.

156 Quem sabe um dia não vira EaD mais formalmente mesmo?

157 Mara: Quem sabe!? Eu adoraria ver um curso desse correndo, já q o

158 próprio BNCC cita ELF, acho q o interesse vai cada dia crescer mais

159 Cristina: Eu não acho impossível, não. Aqui no grupo há muitas feras que

160 se atualizam constantemente e que dão dicas valiosas. Talvez até um

161 MOOC para começar.

162 Carol: está tendo discussão sobre isso no blog do itdi http://itdi.pro/.../the-

163 impact-of-elf-on-teachers-and.../

Carol, after having forged new understandings, starts to participate in different ways: she seems to have changed her role as a novice participant (line 6) to a more central one, as she suggests a link to a blog in which there is a 
discussion on the topic (line 149). Interestingly, too, is the code mixing and the participants feeling more relaxed to use Portuguese.

In the next section, we summarize the ways of acting/interacting of the BrELT community.

\section{WAYS OF ACTING/INTERACTING IN THE COMMUNITY}

What matters to us in these interactions are the ways in which the group discusses and constructs meaning in this community of practice. These interactions show us that their relations are based on respect and interest to learn; there is no recrimination regarding misconceptions and doubts; they share puzzles, ideas and personal experiences, they recognize personal limitations and reveal openness to new learning. This "way of doing things", that is, the way they interact and bring different resources to achieve learning (such as suggesting links, bringing theories, tagging experts, personal stories, showing empathy, giving practical examples, being humble and demonstrating openness to learn) show the members developed shared and common resources that bring together the community and foster learning. To us, it is a clear example of "learning by participating", not only for those participating actively, asking questions and commenting, but also "just reading them" (lurkers).

The table below summarizes their mainly ways of acting/interacting which were crucial to the development of their new understandings of ELF:

\begin{tabular}{|l|l|}
\hline Ways of acting/interacting & Example \\
\hline $\begin{array}{l}\text { Relying on the more } \\
\text { experienced peer }\end{array}$ & $\begin{array}{l}\text { "But I do admit, it's not really something I know a lot } \\
\text { about. So, if it's Mara's specialty, I really want to } \\
\text { listen to her explanation about it". }\end{array}$ \\
\hline $\begin{array}{l}\text { Finding support in external } \\
\text { sources }\end{array}$ & $\begin{array}{l}\text { "English as a lingua franca (ELF) can be thought of as } \\
\text { "any use of English among speakers of different first } \\
\text { languages for whom English is the communicative } \\
\text { medium of choice, and often the only option." } \\
\text { (Seidlhofer 2011:7). }\end{array}$ \\
\hline
\end{tabular}




\begin{tabular}{|c|c|}
\hline $\begin{array}{l}\text { Recognizing they are } \\
\text { "newcomers" when it comes } \\
\text { to ELF }\end{array}$ & $\begin{array}{l}\text { "That is going to be very interesting. As it's not my } \\
\text { area, I really double-checked to avoid saying } \\
\text { something stupid." } \\
\text { "Not my area of expertise/ study either, but I learned } \\
\text { it is not broken English. It's a lot about not having the } \\
\text { focus on on the native speaker as I understood, but I } \\
\text { feel I need to learn more" }\end{array}$ \\
\hline Contrasting ideas & $\begin{array}{l}\text { "it depends on the perspective you analyze it haha } \\
\text { for WE it is a variety, for ELF research it is an } \\
\text { example of innovation and use of multilingual } \\
\text { repertoires for communication through ELF". }\end{array}$ \\
\hline Expressing openness to learn & $\begin{array}{l}\text { "but I feel I need to learn more" } \\
\text { "But I'm really open to learn new points of view" }\end{array}$ \\
\hline Asking for practical examples & $\begin{array}{l}\text { "Could you tell/describe us this particular class and } \\
\text { how you were evaluated? I mean, what have you } \\
\text { been told about this ELF awareness?" } \\
\text { "is there any link describing an ELF example in real } \\
\text { situation? I mean, this awareness of what Luiz has } \\
\text { said"? }\end{array}$ \\
\hline $\begin{array}{l}\text { Accepting the role of } \\
\text { "Expert" }\end{array}$ & $\begin{array}{l}\text { Ex: "Lastly, ELF and EFL are total opposites for one } \\
\text { reason, and you might teach English on an ELF } \\
\text { perspective and you don't even know". }\end{array}$ \\
\hline Becoming aware & $\begin{array}{l}\text { "Wow, Mara. Thank you so much! I kinda have been } \\
\text { aware of ELF, but I didn't know It was ELF let's say. I } \\
\text { have been standing up for other kinds of English } \\
\text { since I went to [name of country] and lived there for } \\
\text { [x] months working at a multinational and teaching } \\
\text { English. From that moment on this focus on native } \\
\text { speakers made no sense for me anymore. I will } \\
\text { definitely study more about ELF!" }\end{array}$ \\
\hline $\begin{array}{l}\text { Expressing } \\
\text { gratitude/recognizing } \\
\text { information brought by the } \\
\text { experts }\end{array}$ & $\begin{array}{l}\text { "It was the Holy grail for me" } \\
\text { "That was really clarifying for me" }\end{array}$ \\
\hline $\begin{array}{l}\text { Showing empathy to the } \\
\text { doubts }\end{array}$ & $\begin{array}{l}\text { "I had to go back to my notes to write this post... } \\
\text { Hah" }\end{array}$ \\
\hline $\begin{array}{l}\text { Questioning and showing } \\
\text { confusion on the topic }\end{array}$ & $\begin{array}{l}\text { "To be honest with you, I still did not really get the } \\
\text { difference" }\end{array}$ \\
\hline
\end{tabular}




\begin{tabular}{|c|c|}
\hline Giving practical examples & $\begin{array}{l}\text { "If you are teaching listening and the audio you use } \\
\text { is of a real life situation of intercultural } \\
\text { communication without any native speakers (or if a } \\
\text { native speaker, native speakers can be part of ELF } \\
\text { too" } \\
\text { "There are some ELF corpora which are very } \\
\text { interesting to observe how ELF is used. You can look } \\
\text { it up. I think there is also a Brazilian ELF corpus } \\
\text { already too" }\end{array}$ \\
\hline $\begin{array}{l}\text { Recognizing doubts and the } \\
\text { challenges of deconstructing } \\
\text { the way we understand } \\
\text { language, even by those } \\
\text { considered the "experts". }\end{array}$ & $\begin{array}{l}\text { "Or even for writing.... but then you would have to } \\
\text { deconstruct a lot more of biases, which has been hard } \\
\text { even for me". }\end{array}$ \\
\hline Suggesting links & $\begin{array}{l}\text { https://worldenglishesblog.wordpress.com/.../elf- } \\
\text { singlish/ }\end{array}$ \\
\hline Sharing personal experiences & $\begin{array}{l}\text { Ex: "Even though I've been there I wasn't aware of } \\
\text { this "elite English". Actually I thought they were } \\
\text { really proud of their way of speaking English and it } \\
\text { wasn't considered "bad English" at all there. Thanks } \\
\text { for sharing! Food for thought!" }\end{array}$ \\
\hline $\begin{array}{l}\text { Evaluating the topics } \\
\text { discussed }\end{array}$ & $\begin{array}{l}\text { "Thanks, R. This was really clarifying for me" (B.) } \\
\text { "It seems to be the Holy Grail for me" (P). }\end{array}$ \\
\hline
\end{tabular}

Table 1: Group's ways of acting/interacting

The multiple ways in which the members of this community interact reveal the potential to learn together and thus strengthen the sense of belonging and mutual commitment. The participants were engaged in expanding their knowledge about ELF as part of their domain (English language teaching).

The group seems to accept new understandings of ELF, moving away from their initial thinking based on the first attempts to conceptualize the various acronyms. Their ways of acting/interacting and consequently, their shared practice, allowed the group to forge these new understandings of the concept:

- ELF is evolving to a multilingual / translingual perspective now and this may slightly change how we see it;

- ELF research is moving to a multilingual perspective, because English does not need to be the only language in intercultural communication; 
- ELF is not a variety to be taught;

- ELF is related to accepting that languages evolve;

- ENL and ELF are totally different things;

- ELF and EFL are total opposites, and you might teach English within an ELF perspective without even knowing it;

- An ELF perspective on teaching empowers teachers and students to own the language for local and global use, in ways that better suit their contexts.

Therefore, BrELT can be defined as a community of ELT professionals who co-constructed learning on ELF, forging new understandings, as teachers' individual trajectories in the interaction were shaped and reshaped by other interlocutors' turns. At the same time, the community also transformed itself and created other artifacts to continue learning: the discussion led to a series of webinars on ELF and there was a suggestion of a distance learning course, which took place later in 2018 and in the beginning of 2019 (the ELF week).

\section{CONCLUSION}

In this paper we aimed at uncovering the understandings about ELF and how they were (re)shaped by the members' interactions in Facebook. What we noticed is that teachers in the BrELT group reconstructed their knowledge on ELF by interacting in democratic ways. It is also clear that it is a community of people who care about this domain. The interactions demonstrate a positive evaluation of the discussion by the peers; members proposing, accepting and discussing the issues they want (ELF, in this case); members sharing ideas, doubts, experiences; relations based on trust, mutual respect and interest to learn; misconceptions not judged in a disrespectful way; members recognizing their personal limitations and showing openness to learn. As in many communities of practice, the combination of more and less experienced members afforded the development of new understandings about the profession. 
As the BrELT community forged the deconstruction of beliefs about English teaching that are hard to be achieved in many contexts, the group revealed to be a potential learning site, as they engaged in the activity and negotiated the new meanings. This group illustrates how social media can play an important role in teacher development, as it can bring together professionals with different levels of expertise who are willing to share their experience. Facebook communities may be a relevant site for teacher development on ELFrelated issues, mainly for continuing professional development. Further research may continue to explore this powerful tool for constructing new and informed pedagogy on ELF.

\section{REFERENCES}

CALVO, L. C. S. Reflexões sobre uma comunidade de prática constituída a partir das interações de formadoras de professores de inglês em um grupo de estudos. 2013. 192f. Tese (Doutorado em Estudos da Linguagem) - Universidade Estadual de Londrina, Londrina.

COSTA, C. O currículo numa comunidade de prática. Sísifo. Revista de Ciências da Educação, Lisboa, n. 3, p. 87-100, 2007.

EL KADRI, M. S. English language teachers'changing identities in a teaching practicum: PIBID and \{Coteaching I Cogenerative Dialogue\} as opportunities for professional learning. 2014. 348 f. Doctoral dissertation (Doctorate in Language Studies) -State University of Londrina, Londrina, 2014.

FAIRCLOUGH, N. Analysing discourse: textual analysis for social research. London: Routledge, 2003.

HALU, R. C. Formação de Formadoras de professores de inglês em contexto de formação continuada (NAP-UFPR). 2010. 246 f. Tese (Doutorado)-Programa de Pós-Graduação em Letras, Universidade Federal do Paraná, Curitiba, 2010.

HERRINGTON, M. ET AL. Space, Resistance, and Identities: University-Based Teacher Educators Developing a Community of Practice. In KIMBLE, C.; HILDRETH, P.; BOURDON, I. (Ed.). Communities of Practice: creating learning environments for educators. Charlotte: Information Age, 2008. v. 1, p. 191-211.

KIMBLE, C.; HILDRETH, P.; BOURDON, I. (Ed.). Communities of Practice: creating learning environments for educators. Charlotte, USA: Information Age, 2008. v. 1.

LAVE, J.; WENGER, E. Situated learning: legitimate peripheral participation. Cambridge, Mass: Cambridge University Press, 1991. 
PERIN, J. O. R. Emergência e construção de uma comunidade de prática de formadores de professores de língua inglesa. 2009. Tese (Doutorado) - Programa de Pós-Graduação em Estudos da Linguagem, Universidade Estadual de Londrina, Londrina, 2009.

WENGER, E. Communities of Practice: learning, meaning and identity. Cambridge, Mass.: Cambridge University, 1998.

WENGER, E. Knowledge management as a doughnut: shaping your knowledge strategy through communities of practice. Ivey Business Journal Online, v. 68, n. 1, Jan./Feb. 2004. Available at: <https://iveybusinessjournal.com/publication/knowledgemanagement-as-a-doughnut/>. Access: Feb 20, 2019.

WENGER, E. Communities of practice: a brief introduction, 2006. Available at: $<$ www.ewenger.com/theory/index.htm>. Access: Mar 15, 2019.

WENGER, E.; TRAUNER, B.; LAAT, M. Promoting and assessing value creation in communities and networks: a conceptual framework. The Netherlands: Ruud de Moor Centrum, 2011.

WENGER, E.; MCDERMOTT, R.; SNYDER, W. M. Cultivating Communities of Practice: a guide to managing knowledge. Boston: Harvard Business School, 2002.

WENGER, E. Learning how to learn. Entrevista concedida a Ryan Howes, Psychotherapy Networker Magazine, Jan./Feb. 2012. Available at:

$<$ www.psychotherapynetworker.org/magazine/recentissues/2012-janfeb/item/1652point-of-view>. Access: July 30, 2012.

\section{Luciana Cabrini Simões Calvo}

Luciana Cabrini Simões Calvo is an Adjunct Professor in the Department of Modern Languages and in the Postgraduate Program on Letras at the State University of Maringá. She holds a Master and a Phd in Language Studies from the State University of Londrina. Her research interests include teacher education, foreign language teaching and learning, communities of practice and English as a lingua franca. She co-edited the books English as a Lingua Franca in Teacher Education: a Brazilian Perspective, published in English by De Gruyter Mouton (2018) and English as a Lingua Franca: Teaching, Learning and Teacher Education, published in Portuguese by Pontes Editores (2011). 


\section{Michele Sales El Kadri}

Michele Sales El Kadri is a lecturer in the Department of Foreign Languages at the State University of Londrina, Brazil. She holds a $\mathrm{PhD}$ in Language Studies (UEL) and a post-doctorate degree in Applied Linguistic by Unicamp. At graduate level, she teaches and supervises students in the graduation Program of Education (PPEDU) and MEPLEM (Professional Master Program of Foreign Languages, UEL) (M.A and Phd levels). At undergraduate levels, she teaches pre-service teachers in the English Language Teacher education program. Dr. El Kadri supervises research in the following fields: English teaching, teacher education, English as a lingua franca, language policy and technology in the teaching of languages. Dr. El Kadri is a researcher funded by Araucária Foundation and and has published several articles and books in referred journals, such as Teacher Development, Teacher Education, Revista Brasileira de Linguística Aplicada, The Routledge handbook of English as a lingua franca, Handbook of Research on Media Literacy in the Digital Age, and Australian Journal of Teacher Education.

\section{Telma Gimenez}

Telma Gimenez, Senior Professor at Universidade Estadual de Londrina (UEL) Postgraduate Program in Language Studies, holds a PhD from Lancaster University (1994) where she developed a study on teacher education, complemented by postdoctoral research at the Institute of Education/UCL (2014) on globalization and English as a Lingua Franca. At postgraduate level she teaches courses on Globalization and Foreign Language Teaching and supervises research on English language teacher education, language policies and English as a Lingua Franca. Dr Gimenez has also coordinated several projects involving English language schoolteachers in communities of practice. She is a researcher funded by CNPq (Science and Technology Agency) and has published more than 150 publications in refereed journals, book chapters, and conference proceedings. She has recently co-edited the book "ELF in teacher education. A Brazilian perspective", published by De Gruyter in 2018. (135 words) 